\title{
Increased fasting and stimulated c- peptide levels after the diagnosis of type 1 diabetes: a case report
}

\author{
Gonca Incemehmet Tamer ${ }^{*}$, Ozge Telci Caklili ${ }^{2}$, Ilkay Kartal ${ }^{1}$ and Hasan Huseyin Mutlu ${ }^{3}$ \\ ${ }^{1}$ Endocrinology and Metabolism, Istanbul Medeniyet University Goztepe Training and Research Hospital, Turkey \\ ${ }^{2}$ Internal Medicine Department, Istanbul Medeniyet University Goztepe Training and Research Hospital, Turkey \\ ${ }^{3}$ Family Medicine Department, Istanbul Medeniyet University Goztepe Training and Research Hospital, Turkey
}

\begin{abstract}
Context: Recently a few studies showing $\alpha$-cell ability to differentiate into insulin-producing $\beta$-cells after prolonged duration of diabetes and reconstruction of new insulin-producing cells in the absence of autoimmunity in mice with completely ablated $\beta$-cells were reported. Here, we present a patient with type 1 diabetes and increased fasting and mixed-meal stimulated $\mathrm{C}$-peptide levels 10 years after the diagnosis.
\end{abstract}

Case description: A female patient with type 1 diabetes for 10 years was referred to our endocrinology clinic for hypoglycemia attacks. Her fasting glucose, HbA1C, fasting and mixed-meal stimulated C-peptide levels were measured three years ago and recently. Fasting and mixed-meal stimulated C-peptide levels were found to be increased compared to the levels of three years ago $(<0.01 \mathrm{ng} / \mathrm{mL}$ vs. $0.06 \mathrm{ng} / \mathrm{mL}$ and $<0.01 \mathrm{ng} / \mathrm{mL}$ vs $0.28 \mathrm{ng} / \mathrm{mL} \mathrm{respectively)}$.

Conclusion: It is possible that $\beta$-cell function may increase in type 1 diabetes, a decade after the diagnosis as observed in our patient. .

\section{Introduction}

Type 1 diabetes (T1D) is a disease with absolute insulin deficiency and it has high short and long term complication rates along with high mortality rate. The decrease in $\beta$-cell function in type 1 diabetic patients varies from patient to patient [1]. Increased endogenous insulin production in patients with type 1 diabetes can improve glycemic control and decrease the complication and mortality rates.

Although destruction of beta cells is believed to be permanent, in recent studies beta cells including insulin were observed in pancreatic autopsy samples obtained from patients with T1D and increased C-peptide secretion after meal stimulus were reported [1,2]. Herein, we present a case with increased fasting and mixed-meal stimulated C-peptide levels, 10 years after the diagnosis of T1D.

\section{Case report}

A 20 year-old woman was admitted to our endocrinology outpatient clinic with the complaints of vertigo and sweating. She stated she had a hypoglycemia attack recently and her glucose level was $50 \mathrm{mg} / \mathrm{dL}$ with glucometer at home when her complaints began. She decreased total dose of daily insulin she used by herself because of the hypoglycemic attacks. She had no weight gain or loss. She is not a smoker and does not consume alcohol. She was diagnosed with T1D 10 years ago. There was no family history of diabetes. Her physical examination was normal. Her anti-glutamic acid decarboxylase (GAD)-antibody was positive at the time of diagnosis and still is. Her metabolic parameters from 2012 are presented in table 1.Her fasting glucose level was found measured with the hexokinase method and her HbAlc level was 10,5\% (91 $\mathrm{mmol} / \mathrm{mol}$ ) measured via high performance liquid chromatography (Tosoh G7 and 2.2, Tokyo, Japan) (Table 1). The C-peptide level was measured via direct electrochemiluminescence immunoassay using mouse monoclonal anti-C- peptide antibody (Immulite 2000,Siemens,
Germany). We performed a mixed-meal tolerance test (MMTT) to the patient after an overnight fasting of $\geq 12$ hours without administering her usual morning insulin treatment. After fasting blood glucose, $\mathrm{C}$-peptide, and HbAlc levels were measured, a mixed meal containing $33 \mathrm{~g}$ of carbohydrate, $15 \mathrm{~g}$ of protein, and $6 \mathrm{~g}$ of fat (240 kcal total) [2] was eaten in less than 10 minutes, and C-peptide level was measured 90 minutes after the mixed-meal. Parameters were confirmed with repetitive measurements.

Total daily insulin dose, fasting glucose and HbAlc level of the patient was decreased and her fasting and mixed-meal stimulated C-peptide levels were increased compared to her levels 3 years ago. Her current laboratory parameters and those in 2012 are shown in Table 1.

\section{Discussion}

It is accepted that T1D is a disease with absolute insulin deficiency. However recent studies have shown endogen insulin secretion is still present in some patients with T1D even in patients with long disease duration [2-4]. In these studies, it was not clear whether $\beta$-cell function was ongoing since the disease begun, or if it has increased or decreased. To our knowledge this case may be the first case in literature with fasting and mixed-meal stimulated C-peptide levels increased compared to the levels three years ago.

Correspondence to: Gonca Incemehmet Tamer, Istanbul Medeniyet University Goztepe Training and Research Hospital, Endocrinology and Metabolism, Fahrettin Kerim Gokay Street, Kadikoy, Turkey, Tel: +90 (216) 5709195; Fax: +90 (216) 5709191; E-mail: hgtamer@yahoo.com

Key words: Type 1 diabetes, $c$ - peptide, mortality

Received: February 02, 2017; Accepted: February 23, 2017; Published: February 25,2017 
Table 1. Differences in patient's laboratory parameters.

\begin{tabular}{|c|c|c|c|}
\hline Metabolic parameters & Year 2012 & Year 2014 & Reference range \\
\hline $\begin{array}{l}\text { Fasting blood } \\
\text { glucose (mg/dL) }\end{array}$ & 168 & 114 & $70-106$ \\
\hline $\mathrm{Hb}$ Alc $\%(\mathrm{mmol} / \mathrm{mol})$ & $13,1(119)$ & $10,5(91)$ & $4-6(20-42)$ \\
\hline $\begin{array}{l}\text { Fasting c-peptide } \\
\text { level (ng/mL) }\end{array}$ & $<0,01$ & 0,06 & $0.90-7.10$ \\
\hline $\begin{array}{l}\text { MMTT stimulated } \\
\text { C-peptide }(\mathrm{ng} / \mathrm{mL})\end{array}$ & $<0,01$ & 0,28 & $0.90-7.10$ \\
\hline $\begin{array}{l}\text { Total daily insulin } \\
\text { dose per kilogram }\end{array}$ & $1.5 \mathrm{U} / \mathrm{kg}$ & $0,14 \mathrm{U} / \mathrm{kg}$ & - \\
\hline TSH (uIU/mL) & 2,3 & 2,1 & $0,27-4,2$ \\
\hline Free T4 (ng/dL) & 1,1 & 0,98 & $0,61-1,12$ \\
\hline $\begin{array}{c}\text { 08:00 am cortisole } \\
\text { level }(\mathrm{uU} / \mathrm{mL})\end{array}$ & 19 & 17,8 & $6,7-22,6$ \\
\hline
\end{tabular}

Based on a murine model Thorel et al. [5] showed that in $\beta$-celldepleted mice, $\alpha$-cells could differentiate into $\beta$-cells after prolonged duration of diabetes. Similarly, Chera et al. [6] observed that pancreas reconstituted new insulin-producing cells in the absence of autoimmunity in mice with completely ablated $\beta$-cells. They also reported that glucagon-producing $\alpha$-cells could begin to produce insulin via a process of reprogramming (transdifferentiation) without proliferation and posited that these phenomena might be translatable to humans, because efficient $\beta$-cell regeneration had been determined in children with type 1 diabetes or after pancreatectomy [6]. Also, glucagon/insulin bihormonal human cells were observed following epigenetic manipulation ex vivo [7], and in diabetic patients [8]. Moreover, Zhou et al reported that aciner cells were capable of conversion into $\beta$-cells invivo when administered an adenovirus cocktail of some transcription factors [9].

Insulin producing $\beta$-cells in patients with long duration of type 1 diabetes have been reported in histological studies since 1965 [10]. These findings can explain the increase in $\beta$-cell function in our case 10 years after the diagnosis.

The source of the increasing $\beta$-cell function observed in our case, is not clear, however there might be multiple reasons. $\beta$-cell proliferation and redifferentiation and/or dedifferentiation of $\alpha$-cells, $\delta$ cells and aciner cells into $\beta$-cells may have led to increase of $\beta$-cell function.

In conclusion, the physiology behind this phenomenon as in our case and how the function of $\beta$-cells in patients with type 1 diabetes can be enhanced remains a question, but discovery of the mechanisms behind this can increase long-term survival and may reduce the incidence of macrovascular and microvascular complications in type 1 diabetes.

\section{Patient consent}

Informed consent has been obtained from the patient (or patient's guardian) for publication of the case report and accompanying images.

\section{References}

1. Rydén A, Ludvigsson J, Fredrikson M, Faresjö M (2014) General immune dampening is associated with disturbed metabolism at diagnosis of type 1 diabetes. Pediatr Res 75: 45-50. [Crossref]

2. Keenan HA, Sun JK, Levine J, Doria A, Aiello LP, Eisenbarth G, et al. (2010) Residual Insulin Production and Pancreatic $\beta$ cell Turnover After 50 years of Diabetes: Joslin Medalist Study. Diabetes 59:2846-2853. [Crossref]

3. McGee P, Steffes M, Nowicki M, Bayless M, Gubitosi-Klug R, et al. (2014) DCCT/ EDIC Research Group. Insulin secretion measured by stimulated c-peptide in longestablished Type 1 diabetes in the Diabetes control and Complications Trial (DCCT/ Epidemiology of Diabetes interventions and Complications (EDIC) cohort: a pilot study. Diabet Med 31: 1264-1268. [Crossref]

4. Oram RA, Jones AG, Besser RE, Knight BA, Shields BM, et al. (2014) The majority of patients with long-duration type 1 diabetes are insulin microsecretors and have functioning beta cells. Diabetologia 57:187-191. [Crossref]

5. Thorel F, Népote V, Avril I, Kohno K, Desgraz R, et al. (2010) Conversion of adult pancreatic alpha-cells to beta-cells after extreme beta-cell loss. Nature 464: 1149-1154. [Crossref]

6. Chera S, Baronnier D, Ghila L, Cigliola V, Jensen JN, et al. (2014) Diabetes recovery by age dependent conversion of pancreatic d-cells into insulin producers. Nature 20.

7. Bramswig NC, Everett LJ, Schug J, Dorrell C, Liu C, et al. (2013) Epigenomic plasticity enables human pancreatic $\alpha$ to $\beta$ cell reprogramming. J Clin Invest 123: 1275 1284. [Crossref]

8. Butler AE, Campbell-Thompson M, Gurlo T, Dawson DW, Atkinson M, et al. (2013) Marked expansion of exocrine and endocrine pancreas with incretin therapy in humans with increased exocrine pancreas displasia and potential for glucagon-producing neuroendocrine tumors. Diabetes62: 2595-2604. [Crossref]

9. Zhou Q, Brown J, Kanarek A, Rajagopal J, Melton DA (2008) In vivo reprogramming of adult pancreatic exocrine cells to beta-cells. Nature 455: 627-632. [Crossref]

10. Foulis AK, Liddle CN, Farquharson MA, Ricmond JA, Weir RS (1986) The histopathology of the pancreas in type 1(insulin-dependent) diabetes mellitus: a 25 year review of deaths in patients under 20 years of age in the United Kingdom. Diabetologia 29:267-274. [Crossref]

Copyright: (C2017 Tamer GI. This is an open-access article distributed under the terms of the Creative Commons Attribution License, which permits unrestricted use, distribution, and reproduction in any medium, provided the original author and source are credited. 